\title{
Productivity of Intercropping with Tomato and Basil under Different Planting Densities at Wondo Genet, Ethiopia
}

\author{
Midekesa Chala Chala Chalchissa \\ Ethiopian Institute of Agricultural Research, Ambo Agricultural Research Center \\ P.O.box, 37, Ambo, Ethiopia
}

\begin{abstract}
Intensive crop cultivation like inter-cropping is a reasonable agronomic practice to fulfill and sustain food security in areas where there is land shortage like that of Wondo Genet areas. An experiment was conducted at Wondo Genet Agricultural Research Center experimental farm to examine productivity and economic return. The experiment was a $2 \times 4$ factorial arrangement in RCBD consisting of ten treatments: two basil row arrangements; one tomato row alternating with one basil row $(1 \mathrm{~T}: 1 \mathrm{~B})$ and one tomato row alternating with two basil rows (1T:2B) and four basil population densities $\left(66666,50000,33333\right.$ and 16666 plants ha $\left.{ }^{-1}\right)$. Results of the study indicated that the intercropping of tomato with basil had a total LER value greater than one which showed the advantage of intercropping over sole cropping of each crop. Intercropping of tomato with basil at $100 \%$ population density gave a total LER value of 1.9 and MAI value of $194600 \mathrm{ETB} \mathrm{ha}^{-1}$, respectively. Therefore, basil with a density of 33,333 plants $\mathrm{ha}^{-1}$ at a spacing of $100 \mathrm{~cm} \times 30 \mathrm{~cm}$ by $1 \mathrm{~T}: 1 \mathrm{~B}$ row arrangements could be recommended for intercropping with tomato in the target area, based on its better compatibility, productivity, and economic benefit.
\end{abstract}

Keywords: Economic return, Land Equivalent Ratio, Monetary Advantage Index

DOI: $10.7176 /$ ALST/91-03

Publication date: January $31^{\text {st }} 2022$

\section{Introduction}

Tomato and basil are common pairs that are intercropped (Bomford, 2009). Several studies reported the performance of inter-cropping of aromatic and medicinal plant species with selected major horticultural crops in Ethiopia and different countries (Bomford, 2004; Neelam and Lokho, 2009; Girma, 2015; Mutisya et al, .2016; Nigussie et al., 2017). Girma (2015) reported inter-cropping of maize with basil at a 1:1-row arrangement could provide farmers with the best yield advantage and income over sole planting of component (maize) crops. Basil and tomato are companion plants that have similar lighting and watering needs, some even say tomatoes taste better when they neighbor basil (Bomford, 2004). According to Carvalho et al. (2017), higher tomato yields have been observed under intercropping with Aromatic plants as compared to tomato alone, so it is a more profitable system. Previous research has also observed that Basil can attract the positive bacteria, Arbuscular mycorrhizal fungi (AMF), and helps prevent diseases in tomatoes, and increases the biomass of tomato (Hage-Ahmed et al., 2013).

Different indices have been suggested for evaluating productivity and efficiency per unit area of land of different crop intercropping systems. Among them, the land equivalent ratio (LER) is the most widely used relative index to evaluate the efficiency and productivity of intercropping (Willey, 1991). The LER could be used either as an index of biological efficiency to evaluate the effects of various agronomic variables (e.g., fertility levels, density and spacing, comparison of cultivars performance, the relative time of sowing, and combinations) on an intercrop system in a locality or as an index of productivity across geographical locations to compare a variety of intercrop systems. It is defined as the area that a sole crop has to occupy to produce the same amount of yield as its component in the intercrop (Mead and Willey, 1980).

Wondo Genet area, which is located in the Sidama zone of southern Ethiopia, is characterized by a rapidly increasing human population, suitable for vegetable production but with the scarcity of arable land per household. There is a need for developing an efficient cropping system to use the limited land efficiently and to enhance food security. Since lack of arable land is a constraint; optimizing inter-cropping performance can assist the effective use of space and nutrients (Lulie et al., 2016). Smallholder farmers in Wondo Genet grow tomatoes both under rain-fed and irrigation. Moreover, growers have been challenged by inconsistent production and low yields. Intercropping vegetables are traditionally common in the Wondo Genet area on small land of the home garden, however, the arrangement of crops is random, and improper planting density of component crops results in poor crop yields. Even though it is possible to increase tomato production by intercropping basil with tomato under proper planting density and row arrangements, yet no scientific research has been done to examine productivity and economic return of tomato-basil intercropping in the study area.

\section{Materials And Methods}

\subsection{Description of the Study Area}

The experiment was conducted in the field at Wondo Genet Agricultural Research Center (WGARC), southern 
Ethiopia, under irrigated conditions in the 2018 dry-off season. The research center is located $264 \mathrm{~km}$ south of Addis Ababa and $14 \mathrm{~km}$ southeast of Shashemene town. It is located in Sidama Zone, Southern Nations Nationalities and People's Region (SNNPR), of Ethiopia at latitude $7^{0} 19^{\prime} \mathrm{N}$ and longitude $38^{\circ} 38^{\prime} \mathrm{E}$ an altitude of 1780 meters above sea level (m.a.s.l). The site has mean annual total rainfall of $1121.8 \mathrm{~mm}$ with mean maximum and minimum temperatures of $26^{\circ} \mathrm{C}$ and $12^{\circ} \mathrm{C}$, respectively. The soil of the study area has clay loam texture ( and $=38$, clay $=37$, and silt $=25$ ) with $\mathrm{pH}$ values of 6.92 , (neutral in reaction) and is low in organic matter content, medium in total N, low in available P, and high in CEC (Lulie et al., 2016). Wondo Genet has a bimodal rainfall distribution with two rainy seasons. Short rains occur from March to May and the long rains from July to October.).

\subsection{Experimental Materials, Design, and Treatments}

Seeds of a tomato variety Melka Shola obtained from Melkassa Agricultural Research Center (MARC) and a promising genotype (B04) of basil from Wondo Genet Agricultural Research Center (WGARC) were used for the experiment. Tomato variety Melka Shola is the determinate type and can be used for dual purposes and well adapted to Wondo Genet conditions. Melka Shola which was released by MARC in 1998, is still widely produced by small-scale farmers and is a high yielder (under farmers condition $30 \mathrm{t} \mathrm{ha}^{-1}$ ) (Benti et al., 2017) and (43 $\mathrm{t} \mathrm{ha}^{-1}$ in research plots) (Regassa et al., 2012). Basil genotype B04 is also a high yielder (herbage and essential oil yields) in the Wondo Genet area (Abewoy, 2018).

The field experiment was laid down in Randomized Complete Block Design (RCBD) with the factorial arrangement in three replications, each with ten treatments (including sole plots of basil and tomato). The experiment consisted of four population densities of basil $(100 \%, 75 \%, 50 \%, 25 \%)$ and two-row arrangements of intercropping tomato (T): basil (B) (1T:1B and 1T:2B), as well as sole plots of tomato and basil, making the total number of treatments ten. A uniform population of 33,333 plants ha-1 with $100 \mathrm{~cm}$ by $30 \mathrm{~cm}$ inters and intra-row spacing, respectively, was maintained for tomatoes in both cropping systems (for sole and intercropped plots). A population of 66,666 plants ha ${ }^{-1}$ with $50 \mathrm{~cm}$ by $30 \mathrm{~cm}$ inters and intra row spacing, respectively, was considered as an optimum density for the sole crop of basil. Besides, four different intercrop proportions of basil: ( $25 \%$ ( 16666 plants ha $\left.\mathrm{h}^{-1}\right), 50 \%$ (33333 plants ha $\left.\mathrm{p}^{-1}\right), 75 \%\left(50000\right.$ plants ha $\left.^{-1}\right)$ and $100 \%\left(66666\right.$ plants ha $\left.\left.^{-1}\right)\right)$ were also maintained in the experiment.

\subsection{Data collection and analysis}

Plant height, Number of branches per plant, Fresh leaf weight per plant (g), Dry leaf weight per plant (g), were recorded from five central plants selected at random. Besides, days to $50 \%$ flowering and days to maturity were recorded. Dry leaf yield ( $\mathrm{kg} / \mathrm{ha})$ and Fresh herbal weight $(\mathrm{kg} / \mathrm{ha})$ weight per hectare was calculated based on dry leaf weight and Fresh herbal weight per plant and converted to the hectare and the average value was computed. Essential oil content was determined by hydro-distillation method, according to the procedure described by Bisrat et al. (2009) and essential oil yield per hectare was determined.

For each measured response variable, analysis of variance (ANOVA) was carried out using Statistical Analysis System (SAS) software version 9.4 (SAS, 2019). Means of treatments showing significant effects were further separated by the least significant difference (LSD) test at $5 \%$ probability level to indicate the minimum difference between mean values under comparison for the variation to be significant or not. The results of the analysis were combined and presented together under the results and discussion.

\section{Result And Discussion}

\subsection{Land equivalent ratio}

The analysis of variance revealed that the interaction of row arrangement and plant population density of basil had a significant $(P<0.05)$ influence on the partial land equivalent ratio of tomato. The mean separation analysis revealed that the highest partial LER of tomato $(0.99)$ was obtained at the interaction of $50 \%$ basil population density with 1T:1B row arrangement, while the least partial LER tomato $(0.70)$ was found at the interaction of $25 \%$ basil population density with 1T:2B row arrangement (Figure 1). This indicated that inter-specific competition between tomato and basil plants was lower than the intra-specific competition for basil plants. De Carvalho et al (2010) reported that the tomato relative yield was higher than 1.0 when in intercrop with fennel and with rue plants. 


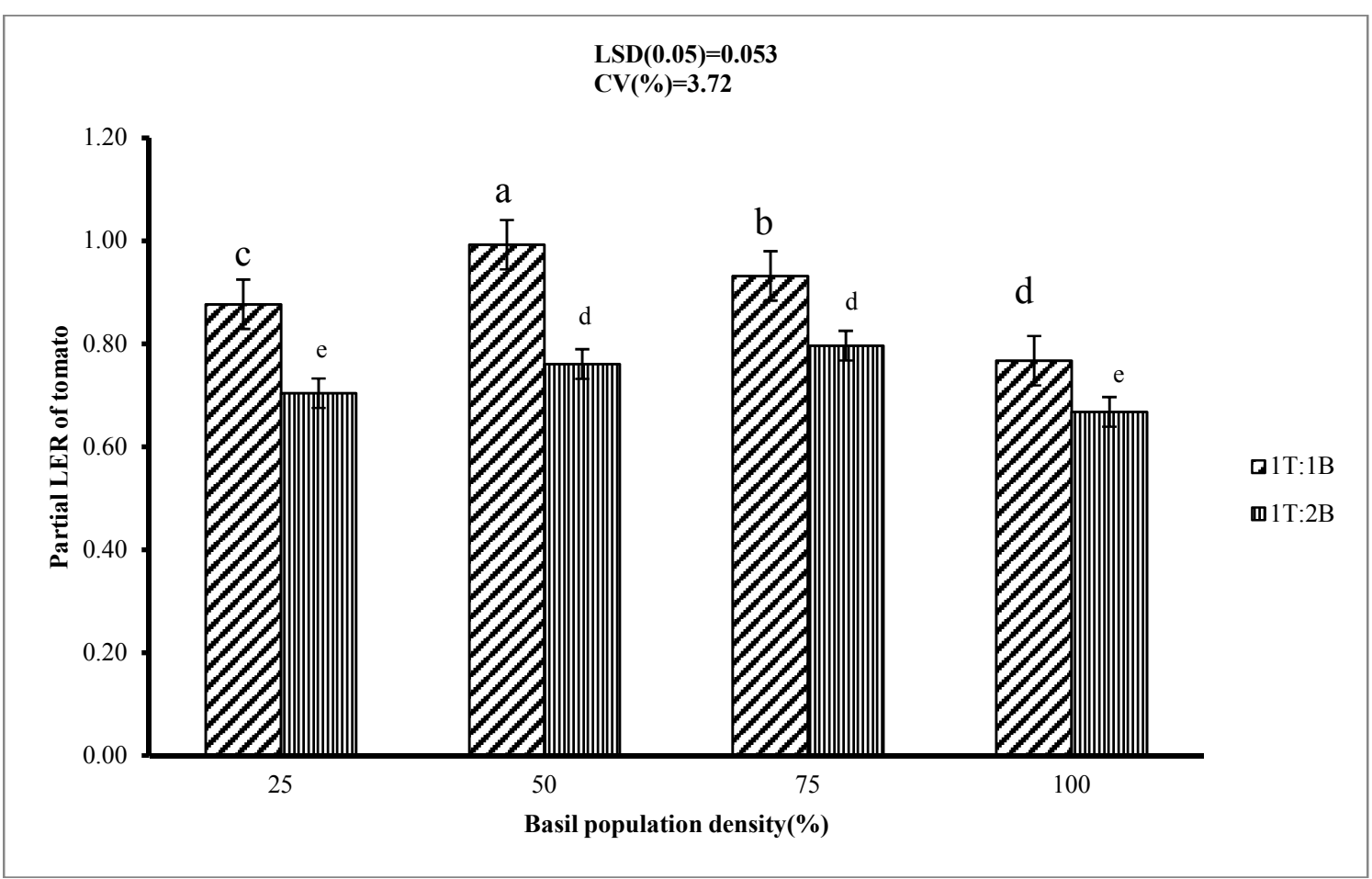

Figure 1. The interaction effect of population density and row arrangement of basil in tomato-basil intercropping on tomato partial land equivalent ratio

The maximum partial LER of tomato was obtained from 1T:1B row arrangement $(0.89)$ as compared to 1T:2B row arrangement (0.73) (Table 1). This result is in agreement with Prakash et al. (2004) who reported that intercropping of tomato in maize in the row ratio of 1:1 recorded the highest land-equivalent ratio (1.86), followed by intercropping of 1 row of tomato within paired rows of maize and 1 row of tomato between 2 paired rows landequivalent ratio (1.79).

Similarly, population density showed a significant $(\mathrm{p}<0.05)$ effect for a partial land equivalent ratio of basil. However, the partial land equivalent ratio of basil was not significantly ( $p>0.05)$ affected by row arrangement and the interaction of main effects. The mean separation analysis revealed that $100 \%$ basil population density was highest for partial LER of basil (1.17) while $25 \%$ basil population density had the least (0.26) partial LER basil (Table 1). This result showed that partial LER of basil increased as basil population density increased in all treatments due to efficient utilization of resources. This result was in agreement with Lulie et al. (2017) who reported partial LER of haricot bean increased as haricot bean population density increased from $25 \%$ to $100 \%$ (0.44-0.76) in maize haricot bean intercropping.

Additionally, the analysis of variance showed that there was no significant interaction effect of row arrangement and population density and row arrangement on total LER, however, the main effects of population density was significantly affected total LER. The highest and lowest LER (1.90 and 1.03$)$ was recorded at $100 \%$ and $25 \%$ basil population intercropped with tomato, respectively (Table 1). This value indicated as basil population density increased in all treatments total LER also increased and the total LER in all cases was more than one (Table 1) showing that intercropping of basil with tomato is more advantageous than sole cropping of tomato. The present study agreement with El-Gaid et al. (2014) who reported that the highest value of LER was obtained from 1 plant tomato: 3 plant common beans (1.26) and the lowest LER values were obtained from 1 plant tomato: 1 plant common bean (1.08).

\subsection{Monetary advantage index (MAI)}

Row arrangement did not show significant $(\mathrm{P}>0.05)$ variation on MAI. However, Population density shows significant $(\mathrm{P} \leq 0.05)$ variation on MAI. Intercropping tomato with basil at $100 \%$, gave the maximum MAI (194600 ETB) which was not statistically different from the MAI obtained from $75 \%$ and $50 \%$ population density ( 185828 and 163131 ETB respectively) (Table 1). Therefore, this value indicated that tomato growers can maximize the land-use efficiency and profit by intercropping tomatoes with basil within limited land at 1T:1B or 1T:2B basil row arrangements and $100 \%$ of basil population density gave extra income. Higher returns under intercropping systems explained the suitability of intercropping systems of tomato with basil and to be adopted on a profitable scale. The result of the present study is in harmony with that of Ijoyah and Dzer (2012) who reported that intercropping gave greater combined yields and monetary returns than those obtained from either crop grown alone. 
El-Gaid et al. (2014) also reported that intercropping of 1 tomato plant: 3 common bean plants could provide economically profitable options for farmers.

Table 1. Productivity measurement of intercropping of tomato as affected by population densities and row arrangement of basil at Wondo Genet during 2017/2018 cropping season

\begin{tabular}{|c|c|c|c|c|}
\hline Treatments & Partial LER of Tomato & Partial LER of basil & Total LER & MAI \\
\hline \multicolumn{5}{|c|}{ Row arrangements } \\
\hline $1 \mathrm{~T}: 1 \mathrm{~B}$ & $0.89^{\mathrm{a}}$ & 0.69 & 1.57 & 158906.00 \\
\hline 1T:2B & $0.73^{\mathrm{b}}$ & 0.77 & 1.51 & 135115.00 \\
\hline $\mathbf{L S D}_{0.05}$ & 0.026 & Ns & ns & ns \\
\hline \multicolumn{5}{|c|}{ Population densities } \\
\hline $100 \%$ & $0.71^{\mathrm{c}}$ & $1.17^{\mathrm{a}}$ & $1.90^{\mathrm{a}}$ & $194600.00^{\mathrm{a}}$ \\
\hline $75 \%$ & $0.86^{\mathrm{a}}$ & $0.88^{\mathrm{b}}$ & $1.69^{\mathrm{b}}$ & $185828.00^{\mathrm{a}}$ \\
\hline $50 \%$ & $0.87^{\mathrm{a}}$ & $0.66^{\mathrm{c}}$ & $1.54^{\mathrm{b}}$ & $163131.00^{\mathrm{a}}$ \\
\hline $25 \%$ & $0.79^{\mathrm{b}}$ & $0.26^{\mathrm{d}}$ & $1.03^{\mathrm{c}}$ & $44484.00^{\mathrm{b}}$ \\
\hline $\mathbf{L S D}_{0.05}$ & 0.37 & 0.17 & 0.18 & 49382.00 \\
\hline CV (\%) & 3.72 & 18.68 & 9.45 & 27.13 \\
\hline
\end{tabular}

Means followed by the same letter in the same column are not significantly different at the $5 \%$ level of probability. $\mathrm{ns}=$ not significant; $\mathrm{RA}=$ row arrangement; $\mathrm{PD}=$ population density; LER=land equivalent ratio; MAI= Monetary Advantage Index

\section{Summary And Conclusions}

In Wondo Genet southern Ethiopia, farmers' livelihoods mainly depend on cash crop production under irrigation and intercropping system. The present experiment was conducted in Wondo Genet Agricultural Research Center, southern Ethiopia under irrigation conditions in the 2017/2018 cropping season to examine yield advantage and economic return of the tomato-basil inter-cropping system under different planting densities and row arrangements. The experiment was arranged in a 4x2 factorial combination in Randomized Complete Block Design (RCBD) consisting of ten treatments including solely tomato and solely basil.

The efficiency of intercropping tomato with basil was significantly affected by basil population density and row arrangement. The highest partial LER of tomato $(0.89)$ was obtained at the interaction of $1 \mathrm{~T}$ : $1 \mathrm{~B}$ row arrangement with $50 \%$ basil population density had the partial LER tomato (0.87), followed by $75 \%$ basil population density (0.86). Partial LER of basil increased as basil population density increased from $25 \%$ to $100 \%$ in all treatments due to efficient utilization of resources. Overall, the highest LER (1.90) was recorded at $100 \%$ basil population intercropped with tomato. Similarly, population density revealed a significant effect on the monetary advantage index. 100\% basil population intercropping gave the maximum MAI (194600ETB) which was not statistically different from the MAI obtained from $75 \%$ and $50 \%$ population density (185828 and 163131 ETB respectively). It could be concluded that different intercropping systems compared to sole did not affect yield and some components of tomato. Therefore, from the practical perspective tomato producer around the study area can maximize the land-use efficiency and profit by intercropping tomatoes with basil at $1 \mathrm{~T}: 1 \mathrm{~B}$ basil row arrangements and $50 \%$ of basil population density.

\section{References}

Abewoy, D., 2018. Influence of harvesting age and genotype on herbage and essential oil yields of sweet basil (Ocimum basilicum 1.) at Wondo Genet, Southern Ethiopia (MSc thesis, Jimma University). pp153-197

Benti, G., Degefa, G., Biri, A., and Tadesse, F., 2017. Performance Evaluation of Tomato (Lycopersicon esculentum Mill.) Varieties under Supplemental Irrigation at Erer Valley, Babile District, Ethiopia. Journal of Plant Sciences. 5(1):1-5.

Bisrat, D., Abate, S. and Kebede, W., 2009. Laboratory manual for plant products analysis. Technical manual. 1 (23): 3-10.

Bomford, M. K.2009. "Do Tomatoes Love Basil But Hate Brussels Sprouts? Competition and Land Use Efficiency of Popularly Recommended and Discouraged Crop Mixtures in Biointensive Agriculture Systems. "Journal of Sustainable Agriculture. 33(4): 396-417.

Bomford, M.K., 2004. Yield, pest density, and tomato flavor effects of companion planting in garden-scale studies incorporating tomato, basil, and brussels sprout (Doctoral dissertation, West Virginia University).

Carvalho, M.G., Bortolotto, O.C. and Ventura, M.U., 2017. Aromatic plants affect the selection of host tomato plants by Bemisia tabaci biotype B. Entomologia Experimentalis et. Applicata.162 (1):86-92.

De Carvalho, L.M., de Oliveira, I.R., Almeida, N.A. and Andrade, K.R., 2010, August. The Effects of Biotic Interaction between Tomato and Companion Plants on Yield. In XXVIII International Horticultural Congress on Science and Horticulture for People (IHC2010): International Symposium.933:347-354.

El-Gaid, A., Al-Dokeshy, M.H. and Nassef, D.M., 2014. Effects of intercropping system of tomato and common 
bean on growth, yield components and land equivalent ratio in new valley governorate. Research Article Science Alert. Asian Journal of Crop Science.6 (3):254-261.

Girma, A., 2015. Yield advantage and economic benefit of maize basil intercropping under different spatial arrangements and nitrogen rates. Scholarly Journal of Agricultural Science. 5 (8):296-302

Hage-Ahmed, K., Krammer, J. and Steinkellner, S., 2013. The intercropping partner affects arbuscular mycorrhizal fungi and Fusarium oxysporum f. sp. lycopersici interactions in tomato. Mycorrhiza, 23(7):543-550.

Ijoyah, M.O. and Dzer, D.M., 2012. Yield Performance of okra (Abelmoschus esculentus L. Moench) and maize (Zea mays L.) as affected by time of planting maize in Makurdi, Nigeria. ISRN Agronomy, 2012:7

Lulie B, Worku W, Beyene S 2016. Determinations of Haricot Bean (Phaseolus vulgaris L.) Planting Density and Spatial Arrangement for Staggered Intercropping with Maize (Zea mays L.) at Wondo Genet, Southern Ethiopia. Acad. Res. J. Agri. Sci. Res. 4(6): 297-320

Lulie, B. 2017. Intercropping Practice as an Alternative Pathway for Sustainable Agriculture: A review

Mead R, Willey RW. 1980. The concept of a land equivalent ratio and advantages in yields from intercropping. Exp. Agric. 16(3):217-228

Regassa, M.D., Mohammed, A. and Bantte, K., 2012. Evaluation of tomato (Lycopersicon esculentum Mill.) genotypes for yield and yield components. Afr. J. Plant Sci. Biotechnol.6:45-49

Mutisya, S., Saidi, M., Opiyo, A., Ngouajio, M. and Martin, T., 2016. Synergistic effects of agro net covers and companion cropping on reducing whitefly infestation and improving the yield of open field-grown tomatoes. Agronomy, 6(3):42.

Neelam, R. and Lokho, P., 2009. Intercropping of medicinal and aromatic plants with vegetable crops-a review. MFP News, 19(2):14-18.

Nigussie, A., Lulie, B. and Chala, M., 2017. Intercropping of Onion with Rosemary as Supplementary Income Generation at Wondo Genet Sidama zone, Southern Ethiopia. Acad. Res.J. Agri. Sci. Res. 5(2): 107-115

Prakash, V., Pandey, A.K., Srivastvn, A. And Guptn, H., 2004. Relay Intercropping Of Hybrid Tomato (Lycopersicoll Esculelltum) In Maize (Zea Mays) Under Mid-Hill Condition Of North-Western Himahlyas. ICAR Publications, 74 (8): 405-8.

SAS Institute, 2019. SAS Version 9. 4 User's Manual.

Willey, R. W., 1981. A scientific approach to intercropping research. In: Proceedings of the International Workshop on Intercropping, International Crops Research Institute for the Semi-Arid Tropics. Andhra Pradesh, India.

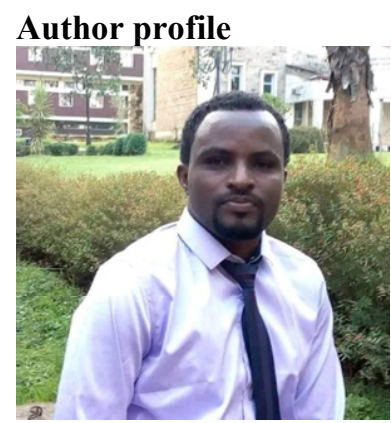

Midekesa Chala, Undergraduate degree in plant science and a postgraduate degree in Agronomy at Jimma University (2012 and 2018). Worked with Ethiopian Institute of Agricultural Research at Wondo Genet and Ambo Agricultural research centers as a crop Agronomist started in 2014 and continued to 2021. Implemented various crop research projects especially, the high-altitude, aromatic, and medicinal crops such as maize, wheat, tomato, bulb onion, lemongrass, artemisia, spearmint, and sweet basil. 